\title{
Internet Resources: Selected Analytical Institutions in Belarus
}

\section{Belarusian Institute for Strategic Studies}

http://belinstitute.eu

The Belarusian Institute for Strategic Studies (BISS) is an independent think-tank based in Minsk. BISS proposes development strategies for Belarus and supports open public policy in the country by conducing research, as well as by promoting dialogue between the expert community, civil society and key political actors. Its publications include BISS Foreign Policy Index, BISS Media Barometer and the Belarusian Yearbook.

\section{Institute for Political Research - Political Sphere}

http://palityka.org

This think-tank prepares analytical and societal analysis. It also conducts various academic activities, publishes the journal 'Palityčnaja Sfera' and is the main organiser of the annual International Congress of Belarusian Studies.

\section{Belarusian Economic Research and Outreach Center (BEROC)} http://eng.beroc.by/

The Belarusian Economic Research and Outreach Center (BEROC) is an economic academic think-tank in Belarus. BEROC conducts academic and applied research, arranges educational programs on modern economics and other outreach activities.

\section{The IPM Research Center}

http://eng.research.by/

Established in 1999, the Research Center of the Institute for Privatization and Management is an independent think tank, specializing in economic and social research. Apart from conducting research, monitoring and forecasting the economic situation in Belarus, the Center promotes professional and public dialogue on national economic development. 


\section{Liberal Club}

http://liberalclub.biz/

Minsk-based Discussion and Analytical Society Liberal Club is a non-profit organisation for research and educational projects. It organises a wide variety of roundtables and conferences in Belarus on social, economic, political and cultural issues.

\section{Centre for Transition Studies}

http://transition-centre.org

The Centre for Transition Studies based in Minsk and London contributes to better understanding of transition processes in Belarus and abroad. Its flagship analytical projects include BelarusDigest.com and the Journal of Belarusian Studies. 